\title{
PLANNING AND CREATING IT PORTFOLIO, A CASE STUDY PT PELABUHAN INDONESIA III
}

\author{
Muhammad Zia ul Haq
}

\author{
muhammad.haq@binus.ac.id
}

\begin{abstract}
Tulisan ini mengangkat 2 (dua) tahap awal yang sangat penting dilakukan dalam Managemen Portofolio TI. Asumsi yang sementara diyakini oleh para peneliti adalah bahwa tidak ada satupun best practice yang baku dan dapat digunakan secara absolut sebagai model yang paling cocok dalam Managemen Portofolio TI. Penulis kemudian melakukan kajian perencanaan dan pembuatan IT Portfolio berdasarkan dokumen TI Pelabuhan Indonesia III. Hasil dari kajian ini menunjukkan bahwa dokumen TI sebuah perusahaan, sangat menentukan model perencanaan dan pembuatan ITPM.
\end{abstract}

\section{Pendahuluan}

Dalam rangka pencapaian tujuan strategis suatu organisasi, selain diperlukan investasi dan usaha yang cukup, juga diperlukan suatu tatanan manajemen yang baik, dimana dengan manahemen ini dapat memaksimalkan pencapaian dari investasi, usaha dan segala sumber daya yang telah dialokasikan. Manajemen Portofolio Teknologi Informasi merupakan proses dan tatanan manajemen yang digunakan dalam rangka perencanaan, pembuatan, penilaian, dan pengomunikasian siklus hidup teknologi informasi dalam sebuah organisasi.

Perencanaan, merupakan langkah awal sekaligus menjadi bagian awal dari beberapa elemen fundamental dalam membangun dan mempertahankan pelaksanaan MPTI. Perencanaan dilakukan untuk mendapatkan aturan main (game plan) untuk tahap awal. Selanjutnya pada tahap kedua dilakukan perencanaan yang melibatkan subportofolio dengan membuat skema kategorisasi pengembangan, presentase target dari alokasi sumber daya yang disepakati. Perencanaan pada tahap ini terdiri dari aktivitas yang sangat menentukan, yakni: 


\section{- Perencanaan strategi investasi}

Adalah langkah untuk:

- Mendefinisikan kategori investasi secara spesifik berdasarkan; tujuan usaha dan perencanaan TI, resiko dan keuntungan, pencapaian dan ukuran.

- Menentukan penggabungan yang sesuai antara kategori investasi dengan menyelaraskan antara tujuan usaha dan tujuan pemanfaatan TI. Serta menentukan toleransi terhadap resiko

\section{- Perencanaan struktur portofolio}

Adalah langkah perencanaan yang dilakukan dengan:

- Menentukan hirarki pengorganisasian portofolio dan menentukan kejelasan perbedaan dari tiap bagian dari portofolio.

○ Mendefinisikan persyaratan/ kebutuhan

- Mendifinisikan berbagai sudut pandang yang terkait dengan portofolio berdasarkan jenis investasi, resiko dan keuntungan

○ Memilih sekumpulan subportofolio

\section{- Perencanaan subportofolio secara tersendiri}

Adalah langkah yang dijalankan dengan

- Menemukan tujuan, metric dan sasaran yang terkait antar setiap subportofolio dengan penyaringan yang ketat.

○ Mengevaluasi dampak dari portofolio

- Memaketkan informasi terkait subportofolio ke dalam rencana portofolio, dengan menjelaskan hubungan trade-off antara berbagai subprotofolio yang berbeda sehingga ditemukan suatu kejelasan. Serta Menyiapkan dokumen komunikasi 
dengan berbagai pihak untuk mencari persetujuan yang final. (Maizlish, 2005:203)

\section{Kajian Perencanaan Portofolio TI PT Pelabuhan Indonesia III (Persero)}

\section{A. Sekilas Pelindo III}

PT Pelabuhan Indonesia III (Persero) atau lebih dikenal dengan sebutan Pelindo 3 merupakan salah satu Badan Usaha Milik Negara (BUMN) yang bergerak dalam jasa layanan operator terminal pelabuhan. Perusahaan dibentuk berdasarkan Peraturan Pemerintah Republik Indonesia Nomor 58 Tahun 1991 tentang Pengalihan Bentuk Perusahaan Umum (Perum) Pelabuhan III Menjadi Perusahaan Perseroan (Persero). Peraturan tersebut ditandatangani oleh Presiden Ke-2 Republik Indonesia Soeharto pada tanggal 19 Oktober 1991.

Pelindo 3 memiliki beberapa bidang usaha yang menjadi bisnis inti perusahaan, yakni:

- Penyediaan dan/atau pelayanan jasa terminal peti kemas, curah cair, curah kering, dan Ro-Ro;

- Penyediaan dan/atau pelayanan jasa bongkar muat barang;

- Penyediaan dan/atau pelayanan jasa dermaga untuk pelaksanaan kegiatan bongkar muat barang dan peti kemas;

- Penyediaan dan/atau pelayanan jasa dermaga untuk bertambat;

- Penyediaan dan/atau pelayanan fasilitas naik turun penumpang dan/atau kendaraan;

- Penyediaan dan/atau pelayanan jasa gudang dan tempat penimbunan barang, alat bongkat muat, serta peralatan pelabuhan;

- Penyediaan dan/atau pelayanan pengisian bahan bakar dan pelayanan air bersih;

- Penyediaan dan/atau pelayanan pusat distribusi dan konsolidasi barang

- Penyediaan dan/atau pelayanan jasa penundaan kapal. [2] 


\section{B. Perencanaan MPTI berdasarkan dokumen Tata Kelola TI Pelindo 3}

Pelindo 3 telah menetapkan baseline tata kelola teknologi informasi di lingkup perusahaan yang tertuang dalam peraturan direksi PT. Pelabuhan Indonesia III (PERSERO) nomer Per.96/05.0102/P-III-2014 tentang Tata Kelola Teknologi Informasi di lingkungan PT. Pelabuhan Indonesia III (PERSERO).

Berdasarkan beberapa poin penjelasan dalam peraturan ini didukung dengan beberapa dokumen lainnya yang terkait dengan perusahaan, disusun perencanaan MPTI melalui 3 (tiga) aktivitas kritikal, sebagai mana yang dijabarkan sebagai berikut:

\section{Perencanaan Strategi Investasi}

Telah dijelaskan pada pendahuluan beberapa aktivitas yang dilakukan sebagai rangkaian perencanaan strategi investasi. Untuk menjalankan aktivitas ini dibutuhkan suatu pendekatan. Berdasarkan topologi dan karakter bisnis Pelindo 3, dimana bidang usaha selain beberapa diantaranya berada dalam area yang saling berjauhan, juga memiliki karakter aktivitas yang berbeda satu dengan yang lainnya, olehnya dipilih pendekatan Hybrid (Top-down dan Buttonup) untuk mendefinisikan rencana strategi investasi.

Selanjutnya rencana strategi investasi disusun berdasarkan 3 (tiga) kategori investasi yang disesuaikan dengan prinsip-prinsip investasi TI berdasarkan surat keputusan Menteri BUMN mengenai Tata Kelola TI, namun tetap mempertimbangkan aspek kebutuhan sesuai karasteristik tiap bidang usaha Pelindo 3 yang dijabarkan dalam Surat Keputusan Dewan Direktur. Adapun rencana strategi tersebut dapat digambarkan kedalam (3 tiga) klasifikasi, Maizlish (2005:205), yakni investasi run the business, grow the business dan transform the business. Penjelasan dari ketiga klasifikasi ini dijabarkan melalui tabel yang setidaknya memuat:

- Item, adalah bentuk investasi

- Spending, jumlah persentase investasi dari total investasi yang direncanakan untuk bidang teknologi informasi 
- Metrics, adalah alat ukur efektiktivitas masing masing item dengan jumlah akumulasi bobot (100) yang diperoleh dari penjumlahan masing masing item investasi. Sedangkan masing-masing kriteria ditentukan bobotnya secara khusus melalui variabel-variabel yang diterapkan pada implementasi teknis, sebagai contoh:

○ Item : Front Desk

○ Kriteria Metrics : Customer Satisfaction

○ Bobot: 30

Contoh diatas berarti bahwa investasi pada proses front-desk akan memiliki dampak efektivitas untuk menunjang terwujudnya kepuasan pelanggan sebesar 30 point.

Beberapa jenis investasi, juga diklasifikasikan sesuai sifat investasi tersebut diantaranya:

\begin{tabular}{|l|l|l|l|}
\hline Nature & Standing & Reward & Risk \\
\hline Core & Critical & Very High & Low \\
\hline Discretionary & Highly Influenced & Moderate & Moderate \\
\hline Nondiscretionary & Mitigating Impact & High & High \\
\hline Venture & Inovation & Very High & Very High \\
\hline Growth & Establish Growth & Moderate & High \\
\hline
\end{tabular}

\section{a. Investasi RTB (Run the business)}

Merupakan investasi yang dimanivestasikan guna terjaga dan berjalannya operasional perusahaan. Investasi ini memerlukan sedikitnya $60 \%$ nilai investasi pada tahun pertama dan kedua dan dapat ditingkatakan sampai $80 \%$ pada tahun ketiga jika direncanakan adanya peningkatan pendapatan perusahaan yang signifikan ditahun tersebut. Adapun deskripsi digambarkan dalam tabel sebagai berikut:

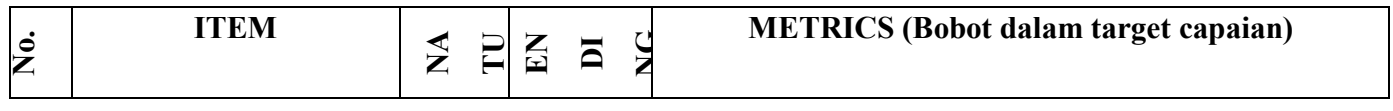




\begin{tabular}{|c|c|c|c|c|c|c|c|c|}
\hline & & & & $\begin{array}{l}\stackrel{\infty}{D} \\
\stackrel{D}{0} \\
\stackrel{\infty}{0} \\
D\end{array}$ & 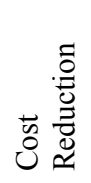 & 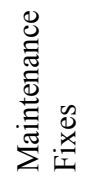 & $\underset{\leftrightarrows}{\leftrightarrows}$ & 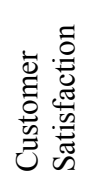 \\
\hline 1 & $\begin{array}{l}\text { Pelayanan front desk } \\
\text { dan layanan pelanggan } \\
\text { online }\end{array}$ & Core & 40 & 10 & 20 & 10 & 30 & 50 \\
\hline 2 & $\begin{array}{l}\text { Digitalisasi } \\
\text { Administrasi keuangan } \\
\text { dan pelaporan }\end{array}$ & Core & 20 & 50 & 10 & 10 & 20 & 20 \\
\hline 3 & $\begin{array}{l}\text { Network and } \\
\text { Datacenter }\end{array}$ & ND & 30 & 20 & 10 & 10 & 20 & 10 \\
\hline 4 & IT Vendor Support & ND & 5 & 10 & 40 & 30 & 10 & 10 \\
\hline \multirow[t]{2}{*}{5} & $\begin{array}{l}\text { Backup \& Disaster } \\
\text { Recovery }\end{array}$ & ND & 5 & 10 & 20 & 40 & 10 & 10 \\
\hline & Total & & $100 \%$ & 100 & 100 & 100 & 100 & 100 \\
\hline \multicolumn{9}{|c|}{$\mathrm{ND}=$ Nondiscretionary } \\
\hline
\end{tabular}

\section{b. Investasi GTB (Grow the Business)}

Merupakan investasi yang ditujukan untuk ekspansi ruang lingkup layanan dan produk ke arah yang lebih luas. Pada investasi GTB ini dialokasikan sebesar 30\% total investasi pada bidang teknologi infomasi di lingkup Pelindo 3 pada tahun pertama.

\begin{tabular}{|c|c|c|c|c|c|c|c|c|}
\hline \multirow[b]{2}{*}{$\dot{\mathbf{Z}}$} & \multirow[b]{2}{*}{ ITEM } & \multirow[b]{2}{*}{ 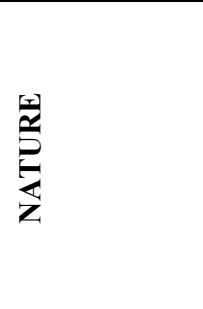 } & \multirow[b]{2}{*}{ 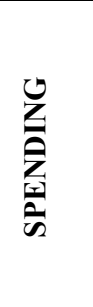 } & \multicolumn{5}{|c|}{ METRICS (Bobot dalam target capaian) } \\
\hline & & & & 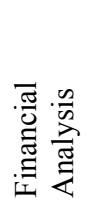 & 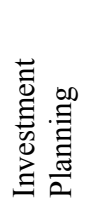 & 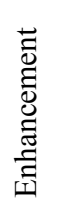 & $\vec{a}$ & 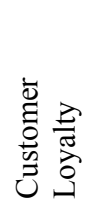 \\
\hline 1 & Pengembangan aplikasi & Growth & 30 & 50 & 20 & 30 & 30 & 20 \\
\hline 2 & $\begin{array}{l}\text { Pengembangan kapasitas } \\
\text { jaringan, server, } \\
\text { workstation dan data } \\
\text { storage }\end{array}$ & Venture & 50 & 30 & 40 & 40 & 40 & 40 \\
\hline 3 & Pelatihan dan workshop & Discretionary & 20 & 20 & 40 & 30 & 20 & 40 \\
\hline \multicolumn{3}{|c|}{ Total } & $100 \%$ & 100 & 100 & 100 & 100 & 100 \\
\hline
\end{tabular}




\section{c. Investasi TTB (Transform the Business)}

Investasi transform the business merupakan investasi yang mengarahkan usaha dapat berpenetrasi dalam percaturan pasar yang baru. Sebaliknya dapat berupa memasukkan usaha atau sumber daya dari pihak lain masuk ke dalam aset perusahaan secara penuh. Alokasi investasi sebesar $10 \%$ dari total investasi pada tahun pertama.

\begin{tabular}{|c|c|c|c|c|c|}
\hline \multirow[b]{2}{*}{$\dot{\mathrm{z}}$} & \multirow[b]{2}{*}{ ITEM } & \multirow{2}{*}{$\frac{1}{\underline{z}}$} & \multirow{2}{*}{ 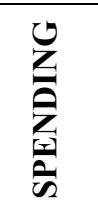 } & \multicolumn{2}{|c|}{ METRICS (Bobot dalam target capaian) } \\
\hline & & & & New Market Share & Future Value \\
\hline 1 & Inovasi baru bidang TI & Venture & 20 & 30 & 30 \\
\hline 2 & Merger dan akusisi & Venture & 20 & 30 & 20 \\
\hline 3 & $\begin{array}{l}\text { Merekerut tenaga ahli baik } \\
\text { terikat maupun tidak terikat }\end{array}$ & Growth & 30 & 10 & 30 \\
\hline 4 & Outsourching & Discretionary & 20 & 20 & 10 \\
\hline 5 & Penambahan aplikasi pendukung & Growth & 10 & 10 & 10 \\
\hline & Total & & $100 \%$ & 100 & 100 \\
\hline
\end{tabular}

\section{Perencanaan Struktur Portofolio}

Sebagaimana yang telah dijelaskan dalam pendahuluan mengenai esensi dari perencanaan struktur portofolio, disusun daftar aktivitas utama sebagai berikut:

\begin{tabular}{|c|c|c|c|}
\hline No & Task & Activity & Parameter \\
\hline 1 & $\begin{array}{l}\text { Mendefinisikan } \\
\text { Persyaratan portofolio TI }\end{array}$ & $\begin{array}{l}\text { - } \text { Menentukan faktor penentu (key factor) } \\
\text { - } \quad \text { Pembuatan dokumen persyaratan yang } \\
\text { diantaranya berupa: } \\
\text { ○ Regulatory, Statutory \& Mandatory } \\
\quad \text { Requirements } \\
\circ \text { Intellectual property \& License } \\
\text { Requirements } \\
\text { O Technical Design, Operating \& }\end{array}$ & Compliance \\
\hline
\end{tabular}




\begin{tabular}{|c|c|c|c|}
\hline & & $\begin{array}{l}\text { Support Requirements } \\
\text { O Skill \& Staffing Requirements } \\
\text { O System-level \& Resource } \\
\text { Requirements } \\
\text { O Review, Reporting \& Financial } \\
\text { Requirement }\end{array}$ & \\
\hline 2 & $\begin{array}{l}\text { Merancang dan } \\
\text { mengarahkan cara } \\
\text { pandang stakeholder }\end{array}$ & $\begin{array}{l}\text { - Mengedintifikasi dan menganalisa } \\
\text { karakter stakeholder } \\
\text { - Mengembangkan metode komunikasi } \\
\text { - Membuat timetable dan menjalankan } \\
\text { komunikasi sesuai dengan timetable } \\
\text { - Membuat dan menjelaskan tujuan, } \\
\text { indikator dan alat ukur. } \\
\text { - Membuat dan sosialisasi laporan }\end{array}$ & $\begin{array}{l}\text { Decision View } \\
\text { Management View } \\
\text { Operational View } \\
\text { Financial View }\end{array}$ \\
\hline 3 & $\begin{array}{l}\text { Determinasi karakteristik } \\
\text { portofolio }\end{array}$ & $\begin{array}{l}\text { Mengedintifikasi sasaran penerapan TI } \\
\text { terhadap bisnis yang dijalankan: } \\
\text { o Ekonomis seperti pengurangan biaya dan } \\
\text { upaya keras (cost \& effort saving) } \\
\text { o Efesiensi, seperti mengurangi waktu } \\
\text { respon terhadap pasar dan pelanggan } \\
\text { o Efektivitas, seperti kualitas, kepuasan dan } \\
\text { performa } \\
\text { o Peningkatan daya, kinerja dan } \\
\text { produktivitas }\end{array}$ & $\begin{array}{l}\text { Market share, ROI } \\
\text { value-added cost } \\
\text { Siklus Proses } \\
\text { Kualitas dan } \\
\text { kepuasan } \\
\text { Tingkat kinerja, } \\
\text { handling time dan } \\
\text { persentasi inovasi }\end{array}$ \\
\hline & Refinemen Sub & - Menyimpulkan dan mengintegrasikan & Readiness dan \\
\hline
\end{tabular}




\begin{tabular}{|l|l|l|l|}
\hline portofolio & ketiga struktur perencanaan sebelumnya. & Maturity \\
& - Penentuan kriteria subportofolio TI & \\
berdasarkan Project, Application, & Infrastructure, People, Process dan & \\
& Information & \\
& Evaluasi, asesmen dan pembuatan & \\
& dokumen refinement. & \\
\hline
\end{tabular}

\section{Perencanaan Subportofolio secara tersendiri}

Portofolio TI dapat diidentifikasikan kedalam 3 (tiga) subportofolio, yakni:

- Discovery Portfolio

- Project Portfolio dan

\section{- Asset Portfolio}

Dalam perencanaan subportofolio untuk Pelindo 3, dilakukan identifikasi elemen dan proses masing-masing subportofolio serta perbedaan capaian yang ditargetkan seperti yang dicantumkan pada tabel berikut:

\begin{tabular}{|c|c|c|c|}
\hline No & Elemen & Proses & Target \\
\hline IT Discovery & $\begin{array}{l}\text { Peluang: Penerapan IT } \\
\text { Discovery sangat sesuai } \\
\text { dengan tujuan strategis } \\
\text { perusahaan yakni penerapan } \\
\text { prinsip-prinsip tata kelola } \\
\text { yang baik. } \\
\text { Orsinil dan berkarakter }\end{array}$ & $\begin{array}{l}\text { Menjalankan secara konsisten usaha-usaha } \\
\text { diantaranya: } \\
\text { - Pelaksanaan proses pengambilan } \\
\text { keputusan yang transparan } \\
\text { - Pelaksanaan pengelolaan usaha yang } \\
\text { efektif dan akuntabel }\end{array}$ & $\begin{array}{l}\text { Terbentuknya sistem, } \\
\text { budaya perusahaan } \\
\text { yang fleksibel serta } \\
\text { adaptif atas berubahan } \\
\text { lingkungan bisnis } \\
\text { yang kompetitif serta } \\
\text { mampu membangun } \\
\text { sistem pengendalian }\end{array}$ \\
\hline
\end{tabular}




\begin{tabular}{|c|c|c|c|}
\hline & $\begin{array}{l}\text { Feasibel dan terjaga } \\
\text { kelangsungannya } \\
\text { Berproses namun dengan } \\
\text { probabilitas kesuksesan yang } \\
\text { tinggi. } \\
\text { Antisipatif terhadap resiko } \\
\text { dan kriteria finansial }\end{array}$ & $\begin{array}{l}\text { - Pengondisian proses usaha secara } \\
\text { mandiri tanpa benturan dan tekanan dari } \\
\text { pihak manapun yang tidak sesuai dengan } \\
\text { aturan } \\
\text { - Penyetaraan dan penerapan keadilan } \\
\text { dalam memenuhi hak-hak pemangku } \\
\text { kepentingan yang ada berdasarkan } \\
\text { perjanjian dan peraturan yang disepakati. } \\
\text { Proses penerapannya diatur dalam Surat } \\
\text { keputusan dewan direktur pasal 2,3 dan } 4\end{array}$ & $\begin{array}{l}\text { internal dan } \\
\text { manajemen resiko } \\
\text { handal }\end{array}$ \\
\hline IT Project & $\begin{array}{l}\text { Menjalankan IT Project } \\
\text { Phase, sebagai contoh } \\
\text { dengan menggunakan Stage- } \\
\text { Gate, Phase-Gate framework } \\
\text { dan IT PPM (PMI) }\end{array}$ & $\begin{array}{l}\text { Penerapan IT Project Management yang } \\
\text { secara rinci diatur dalam surat keputusan } \\
\text { dewan direktur (Pasal 9) }\end{array}$ & $\begin{array}{l}\text { Project dilaksanakan } \\
\text { berdasarkan kaidah } \\
\text { yang baku secara } \\
\text { umum, ditentukan } \\
\text { berdasarkan unit } \\
\text { fungsional dan tim } \\
\text { pelaksananya serta } \\
\text { dikelola sesuai dengan } \\
\text { siklus hidup pekerjaan } \\
\text { implementasi. }\end{array}$ \\
\hline IT Asset & $\begin{array}{l}\text { Investasi yang telah } \\
\text { berjalan/terdapat di } \\
\text { perusahaan seperti data dan } \\
\text { Informasi, Infrastruktur, } \\
\text { Human capital, aplikasi dan } \\
\text { proses. }\end{array}$ & $\begin{array}{l}\text { Diatur dalam surat keputusan dewan } \\
\text { direktur pasal 5, } 6 \text { dan } 7\end{array}$ & \\
\hline
\end{tabular}




\section{Pembuatan (Creation) Portofolio}

Setelah dilakukan perencanaan yang telah dijelaskan pada bagian sebelumnya, langkah selanjutnya yang dilakukan adalah creation IT Portfolio. Pembuatan portofolio TI dilakukan dengan 4 (empat) langkah sebagai berikut:

1. Pengumpulan portofolio (seluruh subportofolio). Pengumpulan ini harus sesuai dengan struktur portofolio, yang diantaranya termasuk:

a. Memastikan akurasi, relevansi, penjadwalan dan kelengkapan inventori, proyek, inisiatif dan investasi yang diajukan.

b. Menemukan keseimbangan antara penilaian secara kualitatif dan kuantitatif, subyektivitas dan obyektivitas dari data dan informasi

c. Mengedetifikasi legitimasi (keabsahan) sumber informasi komponen portofolio

d. Mengendifikasi atribut yang memiliki landasan atau penjelasan terhadap komponen portofolio dengan mencantumkan hubungan, dependensi dan batasan yang jelas.

e. Mengedintifikasi nilai finansial, kualitas dan status serta biaya dan resiko yang timbul selama masa dan siklus hidup berlangsung.

f. Memalidasi kesesuaian alat yang digunakan

g. Mengasosiasikan komponen portofolio dengan kategori investasi

2. Menentukan perkiraan resiko dan hasil yang ingin dicapai dengan:

a. Trade-off kerugian/keuntungan menurut portofolio TI secara menyeluruh, tiap subportofolio dan investasi individual.

b. Kategorisasi resiko dan investasi dengan memparalelkan finansial kategori dengan komponen portofolio. Salahsatu cara yang ditempuh untuk kegiatan ini adalah dengan metode scoring resiko

c. Informasi keuntungan dan nilai yang terukur

d. Inventory dan pengalokasian sumber daya 
3. Menentukan alat ukur untuk menentukan berjalannya proses manajemen portofolio TI, diataranya

a. Membandingkan performa aktual dan rencana portofolioi TI

b. Anggaran TI yang dialokasikan untuk keputusan yang dihasilkan dari framework manajemen portofolio TI

c. Peningkatan Pemasukan dan keuntungan yang didapatkan dari pemanfaatan TI

d. Persentase menurunnya modal yang dikeluarkan untuk proses operasional bisnis

e. Jumlah pengeluaran yang dialokasikan untuk transformasi bisnis (TTB)

f. Pengurangan redundansi proyek

g. Peningkatan produktivitas pekerja

h. Persentase investasi TI yang disertai business case

i. Perbandingan waktu yang digunakan antara proyek strategis dan taktis

j. Survey kepuasan pelanggan

k. Waktu yang digunakan dalam siklus hidup

1. Akurasi kesesuaian antara bisnis dan prioritas strategi

\section{Membuat gambaran portofolio}

Setelah data telah didefinisikan dan dikumpulkan, dilakukan pembuatan gambaran portofolio yang diorientasikan sebagai bahan bagi pemegang kebijakan untuk mengambil keputusan.. Gambaran ini dapat direpresentasikan kedalam gambar, bubble charts, pie charts dan bar charts.

Gambaran ini harus memuat: 
a. Kesesuaian portofolio TI dengan arah dan tujuan perusahaan yang telah dicanangkan

b. Artikulasi yang jelas tentang peluang tercapainya espektasi pihak manajemen perusahaan yang terkait dengan nilai yang diperoleh dan penanganan resiko

Adapun langkah yang dilakukan untuk menghasilkan gambaran ini diantaranya melalui aktivitas berikut:

a. Menentukan poin pengambilan keputusan dan scenario resiko dan keuntungan

b. Menentukan karakteristik dan hubungan yang terjadi pada setiap komponen yang digunakan untuk analisa.

c. Membuat model dan gambaran yang jelas untuk analisa dan pengambilan keputusan

Dari gambaran ini selayaknya dapat diperoleh informasi beberapa aspek:

a. Redundansi investasi

b. Isolasi area usaha yang bersinergi

c. Hubungan, interpendensi infrastruktur, biaya, jadwal, tenaga kerja, teknologi, allternatif dan kompetensi inti

d. Penilaian mengenai sejauhmana seharusnya hasil yang diperoleh dari investasi TI atau sebuah subportofolio dapat memenuhi tujuan jangka pendek dan jangka panjang perusahaan.

\section{Kesimpulan dan Penutup}

Dari kajian diatas dapat diperoleh gambaran mengenai bagaimana perencanaan dan pembuatan Manajemen Portofolio Teknologi Informasi yang dapat diterapkan pada PT. Pelindo 3 berdasarkan dokumen dan fakta manajerial dan operasional yang telah dimiliki dan berlangsung di perusahaan tersebut.

Meskipun beberapa contoh teknis pemanfaatan alat berupa aplikasi yang digunakan dalam Manajemen Portofolio TI belum sempat dipaparkan secara detail, namun kajian ini 
diharapkan sedikitnya dapat memberikan acuan bagi penerapan MPTI di perusahaan tersebut.

\section{Referensi:}

Bryan Maizlish and Robert Handler (2005), IT Portfolio Management Step by Step, Unlocking the business value of technology, John Wiley \& Sons,

https://www.pelindo.co.id/filemanager/userfiles/Tata_Kelola_Teknologi_Informasi.PDF

$\underline{\text { https://www.pelindo.co.id/tata-kelola-perusahaan/tata-kelola-yang-baik }}$

https://www.pelindo.co.id/profil-perusahaan/tentang-kami

http://www.stage-gate.com/

C Betz (2011), Architecture and Patterns for IT Service Management, Resource Planning, and Governance: Making Shoes for the Cobbler's Children, 2nd Edition, Morgan Kaufmann 